\title{
ELEKTRONINIŲ VIEŠŲJŲ PIRKIMŲ BRANDOS VERTINIMO ASPEKTAI
}

\author{
Simona Ereminaitè \\ Mykolo Romerio universitetas \\ Valakupiu g. 5, LT-10101 Vilnius, Lietuva \\ doi:10.13165/VPA-13-12-4-04
}

Anotacija. Straipsnyje nagrinèjama viešuju pirkimu integravimo ị elektroninę erdvę tema, išryškinant Lietuvos Respublikos viešuju pirkimu teisinès bazès kürimo dèsningumus bei Europos Sajungos (ES) elektroniniu viešuju pirkimu institucinio pagrindo ypatumus. Teisès aktu, reglamentuojančiu viešuju pirkimu sriti, lyginamoji analizè leidžia pastebèti pokyčius, ìvykusius nuo Lietuvos įstojimo i ES. Ypatingas dèmesys skiriamas Lietuvos Respublikos viešojo pirkimo ịstatymo kaitos tendencijoms, identifikuojant pirkimo būdus bei pirkimo proceso pokyčius.

Raktažodžiai: elektroniniai viešieji pirkimai, korupcija, valstybès tarnautojai, privatus sektorius, elektroninè valdžia.

Keywords: electronic public procurement, corruption, public service, private sector, electronic government.

\section{Ivadas}

Informacinès visuomenès kūrimas tapo vienu pagrindinių prioritetų ES, todèl svarbūs darbai politinèje ir teisinèje plotmèje prasidèjo dar praejjusiame dešimtmetyje. Elektroninė valdžia yra Lietuvos valstybès valdymo reformos igyvendinimo priemonè, nes informacinèmis technologijomis galima efektyviai įdiegti jos ideologinius pamatus, orientuotus i vartotoją ir verslo valdymo modelių pritaikymą viešujų institucijų darbe. Viešieji pirkimai suprantami kaip viena iš problemiškiausių ES reguliuojamų sričių, kadangi didelẻ kaita būdinga tiek viešųjų pirkimų norminiam reguliavimui, tiek ji aiškinančiai ir taikančiai nacionalinei teismų praktikai.

Remiantis Lietuvos Respublikos teisės aktais, viešasis pirkimas suprantamas kaip perkančiosios organizacijos atliekamas prekių, paslaugų ar darbų pirkimas, kurio tikslas sudaryti viešojo pirkimo-pardavimo sutartį. Viešieji pirkimai yra susiję su prekių ir pas- 
laugų pirkimu bei darbų užsakymu, kuriuos perka arba užsako paprastai viešieji subjektai (pvz., valstybinès arba vietinès valdžios ịstaigos ir joms pavaldžios organizacijos). Nors viešųjų pirkimų praktika yra gana nauja viešajame sektoriuje, tačiau visame pasaulyje žinomas sudètingas šio proceso reguliavimas, koordinavimas bei kontrolè. Viešieji pirkimai igyvendinami nacionalinių ir Europos lygmens ịstatymų pagrindu pagal ekonomiškai naudingiausio pasiūlymo vertinimo kriterijų, perkamų paslaugų specifikacijos ir dalyvavimo viešuosiuose pirkimuose kriterijų aiškumą kitų pretendentų atžvilgiu.

Elektroninių viešųjų pirkimų sistemomis siekiama ịgyvendinti valstybės institucijų nurodymus, ịrankius ar šalies ịstatymų bazę. ES politika orientuota ị korupcijos mažinimą viešuosiuose pirkimuose, siekiant skaidrumo, efektyvumo ir didesnio atvirumo visuomenei, taip užtikrinant teisètą viešųjų pirkimų dalyvių konkurenciją rinkoje.

\section{Viešųjų pirkimų teisinis pagrindas Lietuvos Respublikoje}

Lietuvos Respublikai atkūrus nepriklausomybę kilo būtinybė reglamentuoti už visuomenès lèšas vykdomus pirkimus. Lietuvos Respublikos Vyriausybè 1992 m. gegužès 15 d. prièmé nutarimą Nr. 355 Dèl prekių (paslaugų) įsigijimo tvarkos biudžetinèse įstaigose, kuris nustate, kad iš valstybės, savivaldybių ir socialinio draudimo fondo biudžetų finansuojamos ịstaigos, ịsigydamos prekes ar paslaugas, su tiekejjais atsiskaitytų rinkos kainomis, pirkimų sutartis sudarytų su mažiausią kainą pasiūliusiais tiekejjais. Kiek vèliau atskiru nutarimu patvirtinta Valstybinio užsakymo konkurso, Valstybinio užsakymo sutarties nuostatai ir Valstybinio užsakymo įsipareigojimų nevykdymo nuostolių įvertinimo metodika (1992 m. birželio 9 d., Nr. 444) [18]. Tačiau Lietuvos Respublikos Vyriausybė 1995 m. balandžio 12 d. patvirtino konkretesnes ir aiškesnes Valstybinio pirkimo laikinąsias taisykles, reglamentuojančias pirkimų tvarką bei procedūras. Valstybinio pirkimo laikinosios taisyklès buvo pirmas šiuolaikinis viešuosius pirkimus reglamentuojantis ịstatymas Lietuvoje, užtikrinęs konkurenciją, procedūrų skaidrumą ir atvirumą, tiekẻjų lygiateisiškumą. Šis teisès aktas Lietuvos Respublikos Seime priimtas 1996 m. rugpjūčio 13 d., ịsigaliojo - nuo 1997 m. sausio 1 d. [19, p. 78; 22, p. 1]. Pažymètina, kad Lietuvoje viešuosius pirkimus reglamentuojantis ịstatymas buvo ne kartą keistas ir tobulintas (žr. 1 lentelę). 


\section{1 lentelè. Viešųjų pirkimų reglamentavimo Lietuvos Respublikoje pokyčiai ${ }^{1}$}

\begin{tabular}{|c|c|c|}
\hline Teisès aktas & Pirkimo būdai & Pirkimo proceso pokyčiai \\
\hline $\begin{array}{l}\text { Lietuvos Respublikos } \\
\text { viešojo pirkimo ịstatymas } \\
\text { (1996-08-13, Nr. I-1491) }\end{array}$ & $\begin{array}{l}\text { 1. Atviras konkursas } \\
\text { 2. Uždaras konkursas } \\
\text { 3. Dviejų pakopų konkursas } \\
\text { 4. Konkurencinių derybų } \\
\text { 5. Kainų apklausos } \\
\text { 6. Pirkimo iš vienintelio } \\
\text { šaltinio }\end{array}$ & - \\
\hline $\begin{array}{l}\text { Lietuvos Respublikos } \\
\text { viešųjų pirkimų įstatymo } \\
\text { pakeitimo ịstatymas } \\
(2005-12-22, \text { Nr. X-471) }\end{array}$ & $\begin{array}{l}\text { 1. Atviras konkursas } \\
\text { 2. Ribotas konkursas } \\
\text { 3. Konkurencinis dialogas } \\
\text { 4. Derybos: skelbiamos ir } \\
\text { neskelbiamos }\end{array}$ & $\begin{array}{l}\text { Istatymo nuostatos suderintos } \\
\text { su i̇statymo priede pateiktais ES } \\
\text { teisès aktais } \\
\text { Centrine viešujų pirkimų } \\
\text { informacine sistema siekiama } \\
\text { supaprastinti ir efektyviau vykdyti } \\
\text { viešujjų pirkimų procedūras }\end{array}$ \\
\hline $\begin{array}{l}\text { Lietuvos Respublikos } \\
\text { viešujų pirkimu ịstatymo } \\
86 \text { straipsnio papildymo } \\
\text { ir } 89,119 \text { straipsniu } \\
\text { pakeitimo istatymas } \\
\text { (2007-10-18, Nr. X-1298) }\end{array}$ & $\begin{array}{l}\text { 1. Atviras konkursas } \\
\text { 2. Ribotas konkursas } \\
\text { 3. Konkurencinis dialogas } \\
\text { 4. Derybos: skelbiamos ir } \\
\text { neskelbiamos }\end{array}$ & $\begin{array}{l}\text { Atsiranda reikalavimas, kad } \\
\text { pirkimuose taikant įprastą } \\
\text { komercinę praktiką valstybès } \\
\text { tarnautojai ar darbuotojai būtų } \\
\text { nepriekaištingos reputacijos, } \\
\text { pasirašytų nešališkumo deklaraciją } \\
\text { ir konfidencialumo pasižadèjimą }\end{array}$ \\
\hline $\begin{array}{l}\text { Lietuvos Respublikos } \\
\text { viešuju pirkimų istatymas } \\
\text { (2008-07-03, I-1491) }\end{array}$ & $\begin{array}{l}\text { 1. Atviras konkursas } \\
\text { 2. Ribotas konkursas } \\
\text { 3. Konkurencinis dialogas } \\
\text { 4. Derybos: skelbiamos ir } \\
\text { neskelbiamos }\end{array}$ & $\begin{array}{l}\text { 1) Akcentuojamas tiekejuu } \\
\text { komercinès (gamybinès) } \\
\text { paslapties ir konfidencialių } \\
\text { pasiūlymų aspektų } \\
\text { konfidencialumas } \\
\text { 2) Nuostata, kad sudarant pirkimo } \\
\text { sutarti negali būti keičiama } \\
\text { laimėjusio tiekėjo pasiūlymo } \\
\text { kaina ar galutinè derybų kaina ir } \\
\text { sąlygos } \\
\text { 3) Nuostata, kad pirkimo sutartis } \\
\text { negali būti sudaroma nesibaigus } \\
\text { tiekèjų pretenzijų pateikimo ir } \\
\text { ieškinio pareiškimo terminams } \\
\text { 4)Perkančioji organizacija gali } \\
\text { prašyti dalyvių paaiškinti } \\
\text { pasiūlymus } \\
\text { 5) Numatoma taikyti } \\
\text { supaprastintas pirkimų taisykles }\end{array}$ \\
\hline
\end{tabular}

1 Sudaryta remiantis $10-19$ šaltiniais. 


\begin{tabular}{|c|c|c|}
\hline $\begin{array}{l}\text { Lietuvos Respublikos } \\
\text { viešųjų pirkimų įstatymas } \\
(2009-07-22, \text { Nr. I-1491) }\end{array}$ & $\begin{array}{l}\text { 1. Atviras konkursas } \\
\text { 2. Ribotas konkursas } \\
\text { 3. Konkurencinis dialogas } \\
\text { 4. Derybos: skelbiamos ir } \\
\text { neskelbiamos }\end{array}$ & $\begin{array}{l}\text { Atsiranda nuostata, kad } \\
\text { elektroniniai viešieji pirkimai } \\
\text { kiekvienais metais sudarytų ne } \\
\text { mažiau kaip } 50 \text { proc. perkančiosios } \\
\text { organizacijos viešujų pirkimų } \\
\text { bendrosios vertès }\end{array}$ \\
\hline $\begin{array}{l}\text { Lietuvos Respublikos } \\
\text { viešųjų pirkimų îstatymas } \\
(2010-02-11, \text { Nr. I-1491) }\end{array}$ & $\begin{array}{l}\text { 1. Atviras konkursas } \\
\text { 2. Ribotas konkursas } \\
\text { 3. Konkurencinis dialogas } \\
\text { 4. Derybos: skelbiamos ir } \\
\text { neskelbiamos }\end{array}$ & $\begin{array}{l}\text { Koreguojama ankstesnė įstatymo } \\
\text { redakcija dèl centralizuotų } \\
\text { pirkimų. Perkančioji organizacija, } \\
\text { pirkdama prekių, paslaugų ar } \\
\text { darbų iš centrinės perkančiosios } \\
\text { organizacijos arba per ją, laikèsi } \\
\text { šio ịstatymo reikalavimų, jeigu } \\
\text { jų laikėsi centrinė perkančioji } \\
\text { organizacija }\end{array}$ \\
\hline $\begin{array}{l}\text { Lietuvos Respublikos } \\
\text { viešųjų pirkimų įstatymas } \\
\text { (2011-11-17, Nr. I-1491) }\end{array}$ & $\begin{array}{l}\text { 1. Atviras konkursas } \\
\text { 2. Ribotas konkursas } \\
\text { 3. Konkurencinis dialogas } \\
\text { 4. Derybos: skelbiamos ir } \\
\text { neskelbiamos }\end{array}$ & $\begin{array}{l}\text { Atsiranda nuostata, kad } \\
\text { pirkimo dokumentuose } \\
\text { turi būti informacija apie } \\
\text { numatomą skelbti pranešimą dèl } \\
\text { savanoriško ex ante skaidrumo }\end{array}$ \\
\hline $\begin{array}{l}\text { Lietuvos Respublikos } \\
\text { viešųjų pirkimų îstatymas } \\
(2012-03-29, \text { Nr. I-1491) }\end{array}$ & $\begin{array}{l}\text { 1. Atviras konkursas } \\
\text { 2. Ribotas konkursas } \\
\text { 3. Konkurencinis dialogas } \\
\text { 4. Derybos: skelbiamos ir } \\
\text { neskelbiamos }\end{array}$ & $\begin{array}{l}\text { İstatymu pakeista perkančiosios } \\
\text { organizacijos sąvoka } \\
\text { nustatant, kad perkančiosiomis } \\
\text { organizacijomis nėra laikomos } \\
\text { politinès partijos }\end{array}$ \\
\hline
\end{tabular}

Viešųų pirkimų procedūros Lietuvos Respublikoje nebuvo tiksliai apibrèžtos Lietuvos Respublikos viešojo pirkimo ịstatyme (1996-08-13, Nr. I-1491), ne visai aiški buvo ir pati teisès akto paskirtis, kadangi ịstatymas reglamentavo prekių, darbų, paslaugų viešaji pirkimą už valstybės, savivaldybių biudžetų, valstybinio socialinio draudimo fondo biudžeto ir kitų valstybės fondų lèšas, už valstybès institucijų vardu gautą labdarą ar kitą paramą, kurią suteikęs subjektas nenurodo, kaip ją naudoti, taip pat už valstybės vardu gaunamas arba valstybės garantuojamas užsienio paskolas, jei sutartyse dèl jų panaudojimo nèra numatyta kitokių sąlygų, už įmonių, įstaigų ir organizacijų, finansuojamų iš valstybės, savivaldybių biudžetų bei valstybinių fondų, lěšas, gautas iš jų ūkinès veiklos arba nusavinus ar perleidus jų turtą. Lietuvos narystė ES paskatino detalizuoti viešųų pirkimų procedūras, siekti jų supaprastinimo viešųjų pirkimų proceso ir galutinio rezultato efektyvumo prasmèmis.

Lietuvos Respublikos viešųjų pirkimų ịstatymo pakeitimo ịstatymas (2005-12-22, Nr. X-471) numatė aiškų teisès akto tikslą, vietoj šešių numatyti keturi viešųjų pirkimų būdai, ịtvirtinti lygiateisiškumo, nediskriminavimo, abipusio pripažinimo, proporcingu- 
mo ir skaidrumo principai, kurie vèliau nebuvo koreguojami ar keičiami. Šis ịstatymas buvo vèlesnių teisès aktų redakcijų pagrindas bei orientavosi ị viešųjų pirkimų vykdymą elektroninejje erdveje ir remiantis šiuo pagrindu numatyta sukurti Centrinę viešųjų pirkimų informacinę sistemą (CVP IS). Pabrèžtina, kad kiekviena viešujų pirkimų teisès akto redakcija buvo orientuota ị centralizuotų viešujų pirkimų vykdymą. Nors perkančiosios organizacijos turi teisę viešuosius pirkimus vykdyti pagal supaprastintas viešųų pirkimų taisykles, CVP IS suteikia galimybę efektyviai kontroliuoti viešųjų pirkimų mechanizmo igyvendinimą didesnes teises suteikiant Lietuvos Respublikos viešųju pirkimų tarnybai ir jos vykdomai kontrolei.

Vèlesnis Lietuvos Respublikos viešųjų pirkimų ịstatymas (2008-07-03, Nr. I-1491) ịtvirtino galimybę perkančiosioms organizacijoms prašyti dalyvių paaiškinti pasiūlymus, tačiau komerciniame pasiūlyme nustatyta kaina ir sąlygos jokiu būdu negali būti koreguojamos. Pabrèžtina, kad šis punktas gali būti interpretuojamas dviprasmiškai tiek perkančiųjų organizacijų, tiek tiekẻjų, kadangi abipusiu susitarimu galima sudaryti palankias sąlygas tiekejjams toliau dalyvauti viešajame pirkime bei sudaryti viešojo pirkimo sutartį. Esminis teigiamas viešųjų pirkimų procedūrų pokytis buvo perkančiųjų organizacijų patvirtintų supaprastintų viešujų pirkimų taisyklių paskelbimas ir patvirtinimas. Nors supaprastintos taisyklès neleidžia išvengti viešujų pirkimų procedūrų atlikimo, tačiau ịpareigoja atsakingiau laikytis nustatytų reikalavimų. Lietuvos Respublikos viešųjų pirkimų i̇statymas (2009-07-22, Nr. I-1491) ịpareigojo perkančiąsias organizacijas ne mažiau kaip 50 proc. viešųjų pirkimų vykdyti elektroninèje terpejje ir tokiu būdu užtikrinti skaidrų viešųjų pirkimų procedūrų vykdymą.

Pagal Lietuvos Respublikos viešųų pirkimų ịstatymą (2010-02-11, Nr. I-1491), perkančioji organizacija, pirkdama prekių, paslaugų ar darbų iš centrinès perkančiosios organizacijos arba per ją, laikèsi šio ịstatymo reikalavimų, jeigu jų laikèsi centrinè perkančioji organizacija. Galima pastebèti, kad sustiprinamas centrinès perkančiosios organizacijas vaidmuo bei statusas viešųjų pirkimų procese. Remiantis Lietuvos Respublikos viešųjų pirkimų įstatymo (2011-11-17, Nr. I-1491) pataisomis, patikslintos ịstatymo nuostatos, susijusios su galimybe paskelbti pranešimą dèl savanoriško ex ante skaidrumo. Atsižvelgiant i tarptautinio pirkimo vertès ribą, perkančioji organizacija, paskelbusi pranešimą dèl savanoriško ex ante skaidrumo, išvengtų pirkimo sutarties pripažinimo negaliojančia, jeigu paaiškètų, kad ji pasirinko klaidingai ir vietoj supaprastinto pirkimo turejjo vykdyti tarptautinį. Kartu patikslinami pranešimų dèl savanoriško ex ante skaidrumo vykdant supaprastintus pirkimus. Pažymètina, kad aktuali Lietuvos Respublikos viešųjų pirkimų i̇statymo (2012-03-29, Nr. I-1491) redakcija įnešè skaidrumo reglamentuojant politinių partijų statusą, kadangi jos nėra laikomos perkančiosiomis organizacijomis. Viešujų pirkimų tarnybai ir toliau pavesta kontroliuoti sudarytų viešujų pirkimo sutarčių vykdymą, taip pat vertinti pirkimo sutarčių įvykdymo rezultatus.

Nors Lietuvos Respublikos viešujų pirkimų ịstatymas yra svarbiausias viešųjų pirkimų teisinèje bazèje, tačiau būtina pabrèžti, kad valstybès ar savivaldybès valdymo institucijos, organizuodamos ir vykdydamos viešuosius pirkimus, turi atsižvelgti ị poịstatyminius aktus, kurie papildo pagrindinị Lietuvos Respublikos viešųjų pirkimų įstatymą. 
Poịstatyminių teisės aktų integravimas ị viešųjų pirkimų organizavimo procesą igalina viešojo sektoriaus institucijas reguliariai domètis viešujų pirkimų ịstatymais, atsižvelgiant i viešųju pirkimų tobulinimo galimybes. Apžvelgus Lietuvos Respublikos ịstatymų, reglamentuojančią viešųjų pirkimų tvarką, bazę ir atitinkamas šio proceso igyvendinimo procedūras, galima ižvelgti, kad sudètingas teisès aktų integravimas praktikoje gali paskatinti tam tikrus viešųjų pirkimų procedūrų pažeidimus. Prie viešųjų pirkimų teisinès bazės priskiriami rekomendacinio pobūdžio teisẻs aktai atskirų valstybės institucijų, valdžios ìstaigų ar organizacijų gali būti interpretuojami skirtingai, todèl kiekvieno iš teisès akto paskirties problema gali kelti papildomų klausimų viešuosiuose pirkimuose.

\section{Elektroninių viešųjų pirkimų reguliavimo institucinis pagrindas Europos Sąjungoje}

Viena svarbiausių ES teisès sistemos savybių - teisès nuostatos sukelia tiesioginių padarinių ES valstybių narių teisès sistemoms (institucijoms ir asmenims). Šis ES teisės supranacionalumo (angl. Supranationality) principo komponentas reiškia, kad ES teisei teikiama viršenybė valstybių narių teisès atžvilgiu, todèl viešųjų pirkimų ginčų problemos, visų pirma, sprendžiamos remiantis ES teise ir vykdant jos nuostatas. ES elektroninių viešųju pirkimų teisinę bazę sudaro direktyvos, reglamentai, sprendimai, komunikatai, aiškinamieji dokumentai ir kiti ES teisès aktai. ES viešųjų pirkimų politikos tikslas atverti nacionalines rinkas konkurencijai iš kitų valstybių narių bei pritraukti ị viešųjų pirkimų procesą didesnį pramonės ir verslo įmonių skaičių [25]. ES valdžios sektoriaus pajamos sudaro maždaug 45 proc. bendrojo vidaus produkto (toliau - BVP), o valstybinių valdžios institucijų vykdomi viešieji pirkimai - 15-20 proc., BVP arba 1500-2000 mlrd. EUR per metus [21].

Elektroniniai viešieji pirkimai gali padèti sutaupyti apie 5 proc. visų pirkimų išlaidų ir 10 proc. ar daugiau sumažinti sandorio išlaidas. Tai reiškia, kad būtų galima sutaupyti dešimtis milijardų eurų per metus. Toliau pateikiami ES viešųjų pirkimų politikos įrankiai (priemonès) (žr. 2 lentelę).

SIMAP teikia svarbiausią informaciją apie viešuosius pirkimus Europoje. Viešųjų pirkimų konkursai skelbiami ES Oficialiojo leidinio priede (OL S), kuris prieinamas TED interneto svetainejje. Perkančiosios organizacijos, norėdamos skelbti viešųjų pirkimų skelbimus, gali naudotis interneto įrankiu eNotices, kuris supaprastina ir paspartina viešųjų pirkimų formų rengimą ir skelbimą. Skelbimus galima skelbti naudojantis ir viešųjų pirkimų formų siuntejų eSenders paslaugomis. Šios įmonès gali siųsti pirkimų skelbimus XML formatu tiesiai Leidinių biurui [7]. TED (angl. Tenders Electronic Daily) yra internetinè „ES oficialiojo leidinio priedo“, skirto Europos viešiesiems pirkimams, versija. TED leidžia nemokamai pasinaudoti verslo galimybėmis. Ji atnaujinama 5 kartus per savaitę, paskelbiant apytikriai 1500 viešųjų pirkimų skelbimų iš ES, Europos ekonominès erdvès valstybiu ir kitur. Čia galima naršyti, ieškoti ir rūšiuoti viešųjų pirkimų skelbimus pagal šalị, regioną, verslo sektorių ir kt. Informacija apie kiekvieną pirkimų dokumentą publi- 
kuojama 23 oficialiosiomis ES kalbomis. Šiomis kalbomis publikuojamas visas skelbimų iš ES institucijų tekstas [24].

\section{2 lentelè. ES viešųjų pirkimų politikos ịrankiai (priemonės) (sudaryta autorės)}

\begin{tabular}{|c|l|l|}
\hline $\begin{array}{c}\text { Eil. } \\
\text { Nr. }\end{array}$ & \multicolumn{1}{|c|}{ Pavadinimas } & \multicolumn{1}{c|}{ Aprašymas } \\
\hline 1. & SIMAP & $\begin{array}{l}\text { Europos viešuju pirkimu informacijos sistema, teikianti } \\
\text { svarbiausią informaciją apie viešuosius pirkimus Europoje }\end{array}$ \\
\hline 2. & TED & $\begin{array}{l}\text { ES oficialiojo leidinio priedas, informuojantis apie verslo gali- } \\
\text { mybes visoje Europoje }\end{array}$ \\
\hline 3. & $\begin{array}{l}\text { Europos Komisija - } \\
\text { Jūsų Europa }\end{array}$ & $\begin{array}{l}\text { Viešieji pirkimai ES, visa naudinga informacija, susijusi su } \\
\text { viešaisiais pirkimais: Europos Komisijos viešujų pirkimų teisès } \\
\text { aktai, pagrindiniai dokumentai, kvalifikaciniai reikalavimai, } \\
\text { viešujų pirkimų politikos organizavimo ir procedūrų aprašymas }\end{array}$ \\
\hline 4. & $\begin{array}{l}\text { Pasaulio prekybos } \\
\text { organizacija - WTO }\end{array}$ & $\begin{array}{l}\text { Pasaulio prekybos organizacijos daugiašalè viešujų pirkimų } \\
\text { sutartis, perkančiosioms organizacijoms ir tiekėjams naudinga } \\
\text { informacija }\end{array}$ \\
\hline 5. & $\begin{array}{l}\text { Centrine viešujų } \\
\text { pirkimu informacinė } \\
\text { sistema - CVP IS }\end{array}$ & $\begin{array}{l}\text { Komercinių pasiūlymų teikimas elektroniniu būdu arba centra- } \\
\text { lizuota viešujų pirkimų sistema Lietuvos Respublikoje }\end{array}$ \\
\hline 6. & $\begin{array}{l}\text { Lietuvos Centrinis } \\
\text { viešujų pirkimų } \\
\text { portalas - CVPP }\end{array}$ & NATO skelbimai \\
\hline
\end{tabular}

Europos Komisija yra viena svarbiausių ES institucijų igyvendinant viešųjų pirkimų politiką ir būtent ši ES institucija pasiūlè ES ir jos valstybių narių politinę partnerystę, pripažịstant smulkaus ir vidutinio verslo vaidmens svarbą ES ir pasaulio ekonomikoje. Europos Komisija 2006-2010 m. kartu su valstybėmis narèmis ypatingą dèmesị skyré tarptautinès elektroninių pirkimų sistemos igyvendinimui, kas neatsiejama nuo $2004 \mathrm{~m}$. Elektroninių viešųjų pirkimų veiksmų plano. Sąveiką užtikrinantis prieigos prie viešųjų paslaugų elektroninio identifikavimo valdymas (eIDM), elektroninis dokumentų autentiškumo patvirtinimas ir elektroninis archyvavimas yra kritiškai svarbios igyvendinimo priemonès. Valstybès narès pripažįsta eIDM svarbą, siekiant užtikrinti Europos piliečiams ir verslo įmonėms vietos, regiono ar šalies lygiu teikiamas saugias ir patogias elektronines paslaugas, kurios atitinka duomenų apsaugos reikalavimus ir gali būti prieinamos bet kurioje kitoje valstybejje narēje. Europos Komisijos vaidmuo yra organizuoti bendradarbiavimą Europos lygiu, ypač elektroninio dalyvavimo srityje, didinti informuotumą, spartinti pažangą, dalijantis pakartojamais sprendimais visame pasaulyje, ir pasitelkus informacines ir ryšių technologijas didinti Europos institucijų skaidrumą ir skatinti aktyvesnị 
piliečių dalyvavimą. Pasitarus su ES parlamentais ir kitomis suinteresuotosiomis šalimis, analizuojama geroji patirtis ir ieškoma naujų galimybių parengti bendras priemonių, kurių tikslas - įtraukti piliečius ị parlamentinio sprendimų priëmimo procesą, specifikacijas [9].

Europos Komisijos skelbiamuose elektroninių viešųjų pirkimų konkursuose gali dalyvauti beveik kiekviena juridinio asmens statusą turinti organizacija ir laimèti teisę teikti viešajam sektoriui savo paslaugas, prekes, atlikti darbus. Pasaulio prekybos organizacija (angl. World Trade Organization) teikia naudingą informaciją apie viešuosius pirkimus pasaulyje, ji apima ir ES regioną bei atskiras jos valstybes nares. Kita svarbi institucija viešuosiuose pirkimuose - EuropeAid. Ši tarnyba atsakinga už visos išorès pagalbos, finansuojamos iš ES biudžeto ir Europos plètros fondo, igyvendinimą, išskyrus pasirengimo narystei priemones (PHARE, ISPA ir SAPARD), humanitarinę pagalbą, makrofinansinę pagalbą, bendrosios užsienio ir saugumo politikos ir ,greitosios reakcijos“ programas [5].

CVP IS yra Viešųjų pirkimų tarnybos tvarkoma informacinė sistema, skirta viešųjų pirkimų skelbimams ir ataskaitoms teikti bei tvarkyti, viešujų pirkimų procedūroms atlikti bei informacijai apie viešuosius pirkimus skelbti internete. CVP IS - sistema, kuria besinaudodamos perkančiosios organizacijos elektroniniu būdu gali organizuoti visą viešųjų pirkimų ciklą, o tiekejai vieno langelio principu elektroniniu būdu dalyvauti viešuosiuose pirkimuose. Sistema buvo sukurta vykdant ES struktūrinių fondų ir Lietuvos Respublikos bendrojo finansavimo lěšomis remiamą „Viešųjų pirkimų informacinès sistemos plètros“ projektą (Nr. BPD2004-ERPF-3.3.0-02-04-0017) [1]. Šiandien praktikoje susiduriama su problema, kai elektroninėmis priemonèmis sudètinga vertinti pasiūlymus ne pagal mažiausios kainos, bet ekonomiškai naudingiausią vertinimo kriterijų. Galima teigti, kad CVP IS dar neịgalina visų viešojo pirkimo procedūrų vykdyti internetinejje plotmėje.

Europos socialinio fondo agentūra pristatė studiją „Teismų praktikos apžvalga dèl kvalifikacijos reikalavimų tiekejams nustatymo ir jų vertinimo“, kurioje pateikiama išsami teismų praktikos analizė bylose dèl perkančiųjų organizacijų nustatytų kvalifikacijos reikalavimų ir jų vertinimo [23]. Tokia praktika nèra gausi, tačiau iš esmės vienareikšmè. Tiek Europos Teisingumo Teismas, tiek nacionaliniai teismai, aiškindami viešųų pirkimų nuostatas, pažymėjo perkančiosios organizacijos pareigą, atsižvelgiant ị pirkimo objekto specifiškumą. Ypač svarbūs yra šie aspektai: nustatyti tikslius, aiškius, proporcingus, pagrịstus kvalifikacijos reikalavimus ir tinkamai juos įvertinti, t. y. įsitikinti, ar tiekejai visiškai atitinka šiuos reikalavimus, sudarant galimybę tiekẻjams naudotis kitų asmenų pajègumais ir visomis kitomis ES ir nacionaliniuose teisès aktuose ịtvirtintomis teisèmis. Atsižvelgiant ị tai, kad iggyvendinant projektus projektų vykdytojų (ar partnerių) patirtos išlaidos kompensuojamos tik tuo atveju, jei projekto veikloms ịgyvendinti skirtos prekès, paslaugos ar darbai buvo įsigyti vadovaujantis viešujų pirkimų teisine baze, teigiama, kad perkančiosios organizacijos pirkimo dokumentuose nustatyti tikslūs, aiškūs, proporcingi ir pagrịsti kvalifikacijos reikalavimai bei tinkamas jų ịvertinimas yra viena iš pagrindinių sąlygų, lemiančiu sèkmingą projekto ịgyvendinamą. Pirkimo dokumentuose projektų vykdytojų (ar partnerių) nustatyti viešųjų pirkimų teisès aktų nuostatas atitinkantys kvalifikacijos reikalavimai leidžia ịsigyti kokybiškesnes prekes, paslaugas ar darbus, t. y. tinkamai panaudoti 2007-2013 m. ES struktūrinę paramą. 
E. valdžios priemonių kūrimas ir diegimas yra neatsiejamas nuo aukštųjų technologijų plètros, šalies inovacijų skatinimo politikos ir žinių ekonomikos raidos. Informacinès ir ryšių technologijos (IRT, angl. Information and communication technologies), moksliniai tyrimai ir jų rezultatų pritaikymas praktikoje gali padèti patobulinti egzistuojančius elektroninius procesus, operacijas ir paslaugas. E.valdžios projektai atskleidẻ didžiules galimybes valstybiu socialinei ir ekonominei raidai, tačiau jų išnaudojimas priklauso ne tik nuo politinès valios, bet ir nuo technologinių sprendimų bei egzistuojančių intelektinès nuosavybès režimų ir paskatų plètoti žinioms imlias sritis.

\section{Elektroninès valdžios instrumentų viešųjų pirkimų procese analizė}

Šiuolaikinè, greitai kintanti ir kompleksiška žinių visuomenė formuoja vis naujus iššūkius e. valdžios sprendimams, todèl keliami reikalavimai tobulinti IRT naudojimą ir pritaikyti vis modernesnes technologines priemones, igalinančias greitesnę, paprastesnę ir labiau prieinamą komunikaciją [8]. Valstybès modernizavimui bei žinių ekonomikos

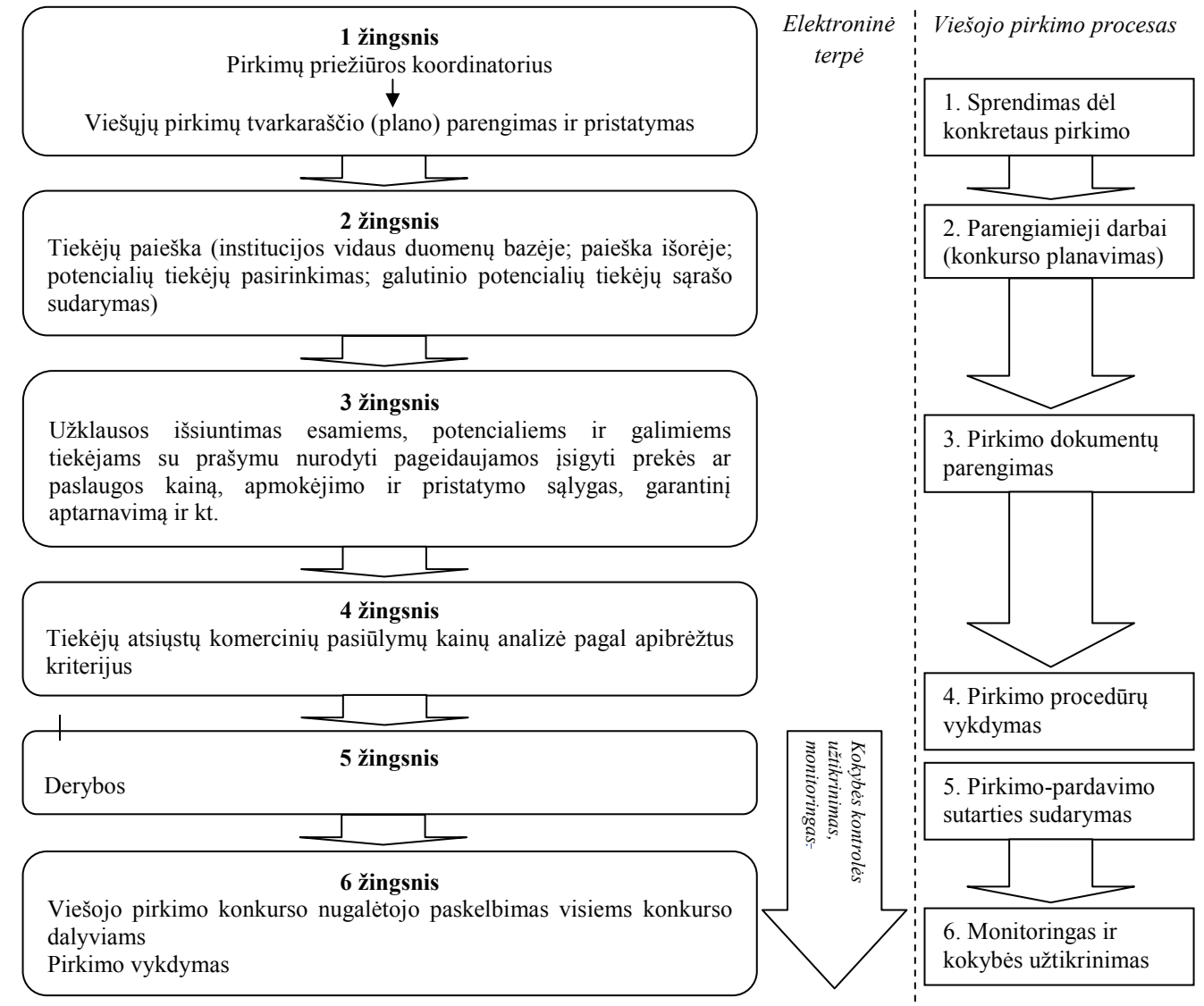

1 pav. Elektroninių viešųų pirkimų procesas (sudaryta autorès) 
plètrai itin svarbios yra e. valdžios sritys [20]. Nors didžioji viešųjų paslaugų dalis turi savo specifinius ypatumus, tam tikros paslaugų nuotolinio teikimo problemos gali ir turi būti sprendžiamos centralizuotai ir pagal vieno langelio principą: viešųjų paslaugų gavėjų elektroninis autentifikavimas, elektroninio parašo infrastruktūra, centralizuota dokumentų valdymo sistema, organizacinių ir teisinių pokyčiu nustatymas bei inicijavimas [4; 26].

Elektroninių viešųjų pirkimų procesas (kaip ir įprastas viešųjų pirkimų procesas) gali būti skirstomas ị šešis etapus (žingsnius): 1) viešujų pirkimų tvarkaraščio parengimas ir pristatymas; 2) tiekejų paieška; 3) užklausos išsiuntimas ir atrankos kriterijų apibrèžimas; 4) komercinių pasiūlymų ir kainų analizė; 5) derybos; 6) laimètojo paskelbimas ir viešojo pirkimo vykdymas (žr. 1 pav.).

Galima įžvelgti, kad informacinès technologijos suteikia naujų galimybių stebèti viešojo pirkimo procesą nuo poreikio pirki identifikavimo iki sutarties vykdymo kontrolès. Elektroniniai viešieji pirkimai ir ịprastai vykdomi viešieji pirkimai savo paskirtimi, funkcijomis ir galutiniu adresatu nesiskiria vienas nuo kito. Galima teigti, kad viešieji pirkimai, perkelti ị elektroninę terpę, paspartina informacinių technologijų, žmogiškųjų išteklių plètotę organizacijoje, todèl laikui bègant eliminuojami biurokratiniai trukdžiai ir valstybès tarnautojų nelankstumas. Siekiant viešosios ir privačios partnerystès, visų pirma, būtina derinti abiejų pusių interesus, kadangi tik tada galima subalansuota ekonomikos plètra.

Ekonominio nuosmukio laikotarpiu aktualus valstybės biudžeto taupymas, kuris neatsiejamas nuo skaidrių viešųjų pirkimų. Elektroniniai viešieji pirkimai palengvina perkančiųjų organizacijų ir tiekẻjų bendravimą, padidina viešųjų pirkimų skaidrumą, pagreitina viešųjų pirkimų procesus, skatina demokratijos principų išsaugojimą bei ịtraukia perkančiąsias organizacijas ir tiekejjus ị centralizuotą viešųjų pirkimų sistemą. Registruotos elektroninių viešųjų pirkimų sistemoje perkančiosios organizacijos gali vykdyti elektroninius pirkimus, o registruoti tiekejjai - dalyvauti tokiuose pirkimuose. Pabrežtina, kad registracija elektroninių viešųjų pirkimų sistemose dažniausiai yra nemokama ir atskirai vykdoma perkančiosioms organizacijoms ir tiekejams. Centralizuota informacinè sistema suteikia galimybes ne tik vykdyti viešuosius pirkimus, bet ir siųsti užklausas ar prašyti iš perkančiosios organizacijos bei tiekejjų patikslinti informaciją. Prieš registruojantis elektroninių viešųjų pirkimų sistemoje būtina susipažinti su registracijos taisyklèmis ir privatumo politika. Čia taip pat saugomi duomenys iš juridinių asmenų registro, todèl, įvedus juridinio asmens kodą, galima užpildyti kitus registracijos anketos laukus. Organizacija gali sukurti tiek vartotojų, kiek jai jų reikia, tačiau perkančioji organizacija, norẻdama vykdyti elektroninius pirkimus, privalo elektroninių viešųjų pirkimų sistemoje sukurti visus Viešojo pirkimo komisijoje dalyvaujančių asmenų naudotojus. Norėdama elektroniniu būdu atlikti vokų atplèšimo procedūrą perkančioji organizacija privalo elektroninių viešujjų pirkimų sistemos priemonėmis sudaryti komisiją, sukuriant jos narių naudotojų profilius, sukurtus naudotojus sujungiant į bendrą naudotojų grupę ir inicijuojant elektroninị pirkimą, kai pasirenkama naudotojų grupè, kurios nariai galès vykdyti vokų atplèšimo procedūrą. Dažniausiai kiekvienam registruotam naudotojui yra suteikiamos galimybės tvarkyti bet kokių formatų elektroninius dokumentus: įkelti, saugoti bei šalinti. Perkančiosios or- 
ganizacijos turi galimybę sukurti ir jos vykdomuose elektroniniuose pirkimuose naudoti klausimų tiekejjams šablonus, kurie priklausomai nuo perkančiosios organizacijos poreikių gali būti naudojami viename ar keliuose pirkimuose. Klausimų šablonai naudojami tikrinant tiekèjų atitiktį minimaliems kvalifikacijos reikalavimams, tačiau šablonai gali būti naudojami ir kitiems tikslams (pvz., perkančioji organizacija gali nustatyti klausimus, leidžiančius tiekẻjams pateikti kitą pasiūlymo informaciją). Sukurtame šablone perkančioji organizacija sukuria aktualius klausimus ir, vykdydama skelbiamą pirkimą, informaciją pateikia elektroninių viešųjų pirkimų sistemos skelbimų sąraše. Tiekèjas, norėdamas dalyvauti tokiame pirkime, privalo patvirtinti norą jame dalyvauti. Perkančiajai organizacijai vykdant neskelbiamą pirkimą, informacija apie tokị pirkimą neskelbiama viešai, kadangi perkančioji organizacija pati kviečia pasirinktus tiekèjus dalyvauti viešajame pirkime [2; $3 ; 6]$.

Hierarchinè valstybės tarnautojų ir politikų atsakomybė gali iš esmès pakeisti jų požiūrị ị viešuosius pirkimus ir paskatinti juos veikti vengiant viešųjų ir privačių interesų konflikto valstybės tarnyboje. Sudarius Viešojo pirkimo komisiją ir rengiantis viešojo pirkimo konkursui svarbu numatyti perkamos prekès, paslaugos ar darbų specifikacijas. Būtina vengti pernelyg detalių specifikacijų, atitinkančių konkretaus tiekejjo pasiūlymą, nes tokiu atveju yra iškraipomi konkurenciniai santykiai. Valstybės tarnautojai turi būti suinteresuoti savivaldybès biudžeto planavimu, vengti politinių partijų ịtakos ir veikti visuomeniniais pagrindais. Institucijų nepriklausomumą įtvirtintų valstybés tarnautojų skatinimas, atsižvelgiant ị viešojo pirkimo naudingumą, kuris būtų matuojamas pirkimo kainos ir kokybès santykiu bei naudingumu visuomenei. Skaičiuojant pirkimo vertes ir numatant pirkimo būdą galimos korupcinio pobūdžio veikos pasireiškia perkančiosios organizacijos ir tiekèjo susitarimuose bei pirkimo specifikacijų nepaisymu, todèl būtina didinti valstybės tarnautojų atsakomybę už priimamus sprendimus, numatant ne tik nušalinimo nuo pareigų, bet ir atleidimo iš valstybès tarnybos be teisès ị ją grị̌ti galimybę. Analogiški susitarimai pasitaiko ir pirkimo dokumentų parengimo etape, kai yra primetamos tiekejjo sąlygos ir valstybės tarnautojui numatoma atitinkamo dydžio išmoka už neteisètą veiką. Teikiant pirkimo dokumentus, paraiškas ir pasiūlymus rekomenduotina teikti informaciją CVP IS apie kiekvieną konkurse dalyvaujantị tiekèją, numatyti atsakomybę už viešojo intereso ignoravimą, pirkimo tvarkos pažeidimą. Vokų su pasiūlymais atplěšimo procedūra turi vykti LR viešųjų pirkimų ịstatymo numatyta tvarka, o ịstatymo pažeidimai turi būti užfiksuojami. Vertindama ir lygindama pasiūlymus Viešojo pirkimo komisija turi orientuotis ne tik ị pasiūlymuose pateiktas kainas, bet ir domètis rinkos tendencijomis, ịvertinti siūlomos prekès, paslaugos ar darbų kokybę. Viena iš egzistuojančių problemų viešuosiuose pirkimuose - valstybès tarnautojų abejingumas ir nenoras taupyti mokesčių mokètojų pinigų. Siekiant išvengti tiekejjų pretenzijų ir skundų nagrinejjimo, svarbu iš anksto prašyti galutinès pirkimo kainos ir visų numatomų išlaidų sąmatos. Tuo tarpu sudarant sutartị būtina reikalauti viešojo pirkimo objekto specifikacijų, kuriose galimi anksčiau pateikto komercinio pasiūlymo neatitikimai. 


\section{Išvados}

1. Remiantis Lietuvos Respublikos viešųjų pirkimų teisinès bazès analize, pažymėtina, kad nuo pat viešujų pirkimų reglamentavimo pradžios orientuojamasi ị ekonominį naudingumą - mažiausią tiekejjų siūlomą kainą bei jos pasirinkimą, nes akcentuojamas valstybès lèšų taupymas ir ekonomiškiausio sprendimo prièmimas. Praktikoje neretai tiekèjai užmaskuoja viešojo pirkimo objekto technines savybes arba neįvardija svarbių parametrų. Viešųu pirkimų reglamentavimas yra pernelyg standartizuotas, kadangi viešojo pirkimo procesas vyksta tam tikrais etapais ir deklaruojant vykdomų procedūrų nuoseklumą, todèl vis dažniau atsiranda galimybės manipuliuoti viešojo pirkimo procesu pažeidžiant etikos principus ir apeliuojant ị sąžiningos rinkos konkurencijos užtikrinimą.

2. Elektroninėmis priemonėmis siekiama, kad viešiesiems pirkimams skiriamos lèšos būtų naudojamos teisètai, ekonomiškai, efektyviai ir rezultatyviai. Skaidresnis valstybės valdymas, valstybės tarnautojų asmeninė atsakomybė, aiški atskaitomybės sistema, skaidrūs sprendimų prièmimo mechanizmai yra esminiai efektyvaus valdymo aspektai. Akcentuotina, kad Lietuvos Respublikos viešųjų pirkimų teisinèje bazèje būtina numatyti vadybinius elektroninių viešųjų pirkimų sprendimus (pirkimo planavimas, komitetų sudarymas, perkančiųjų organizacijų ir tiekẻjų atsakomybès bei funkcijų apibrèžimas, komercinių pasiūlymų vertinimo procedūros detalizavimas, sutarčių vykdymo monitoringo užtikrinimas).

3. Tinkamam elektroninių viešųjų pirkimų igyvendinimui nemažai įtakos turi valstybès teisinè bazè, kurios tobulinimas yra siejamas su atitinkamų kliūčių šalinimu. Siekiant vykdyti tarpvalstybinius elektroninius viešuosius pirkimus ir sukurti elektroninių viešųjų pirkimų informacinę sistemą būtina suderinti atitinkamas teisès normas, kadangi skirtingose šalyse skiriasi kvietimo pateikti perkančiajai organizacijai pasiūlymą procedūra, egzistuoja skirtingas viešumo laipsnis. Kiekviena situacija reikalauja lankstumo ir neretai negalima apibrēžti visų viešojo pirkimo proceso etapų, todèl ị viešojo pirkimo procesą reikia žiūrèti liberaliau. Neretai globalioje rinkoje skiriasi viešojo pirkimo sutarties sudarymo procedūros bei pagrindinio kriterijaus apibrèžimo esmè. Esama valstybių, kuriose pagrindinis kriterijus yra ne prekès ar paslaugos kaina (ekonomiškumas), o kokybè (efektyvumas ir utilizavimas).

\section{Literatūra}

1. Apie Centrinę viešųjų pirkimų sistemą. CVP IS, 2010. https://pirkimai.eviesiejipirkimai.lt/ ppo_startpage/apiecvpis.htm.

2. Barnes, S., Hunt, B. E-commerce and v-business - Business Models for Global Success. Great Britain, 2001.

3. Davila, T., Gupta, M., Palmer, R. J. Moving Procurement Systems to the Internet: The Adoption and Use of E-Procurement Technology Models. European Management Journal, 2003, 11-23.

4. Elektroninių viešųjų paslaugų modelio igyvendinimo aprašymas. http://www.epractice.eu/ files/media/media_253.pdf [2012-05-25]. 
5. EuropeAid. European Commision, 2010. http://ec.europa.eu/europeaid/who/index_en.htm [2012-09-02].

6. Gatautis, R. The Impact of ICT on Public and Private Sectors in Lithuania. Engineering Economics, 2008, 4(59), 18-28.

7. Information system for European public procurement. SIMAP, 2010. http:/simap.europa.eu/ index_en.htm [2012-08-16].

8. Information Technology, Research, Innovation and E-Government. Washington DC: National Academy Press, 2002.

9. Komisijos komunikatas Tarybai, Europos Parlamentui, Europos ekonomikos ir socialinių reikalų komitetui ir Regionų komitetui - i2010 e.vyriausybès veiksmų planas - e. vyriausybès plètros spartinimas Europoje visų labui $\{\operatorname{SEK}(2006) 511\}$. EUR-Lex, 2006. http://eur-lex.europa.eu/ LexUriServ/LexUriServ.do?uri=CELEX: 52006DC0173:LT:NOT [2012-06-15].

10. Lietuvos Respublikos viešojo pirkimo įstatymas. Valstybės žinios, 1996, Nr. 84-2000.

11. Lietuvos Respublikos viešųjų pirkimų ịstatymas. Valstybės žinios, 2010, Nr. 1491.

12. Lietuvos Respublikos viešųjų pirkimų ịstatymas. Valstybės žinios, 2011, Nr. 1491.

13. Lietuvos Respublikos viešųjų pirkimų įstatymas. Valstybès žinios, 2012, Nr. 1491.

14. Lietuvos Respublikos viešujų pirkimų ịstatymo 2, 4, 7, 8, 10, 11, 16, 18, 19, 22, 23, 24, 27, 28, $30,33,39,40,43,45,49,57,62,74,85,86,89,92$ straipsnių pakeitimo ir papildymo, Istatymo papildymo 15(1) straipsniu ịstatymas. Valstybès žinios, 2009, Nr. 93-3986.

15. Lietuvos Respublikos viešųjų pirkimų įstatymo 2, 6, 7, 8, 9, 10, 11, 12, 16, 17, 18, 19, 22, 23, 24, $27,28,30,31,33,38,39,41,51,57,58,70,72,75,79,81,93,95,98,100$ straipsnių, IV skyriaus, 1 ir 2 priedèlių ir priedo pakeitimo ir papildymo įstatymas. Valstybės žinios, 2008, Nr. 81-3179.

16. Lietuvos Respublikos viešųų pirkimų ịstatymo 86 straipsnio papildymo ir 89, 119 straipsnių pakeitimo įstatymas. Valstybès žinios, 2007, Nr. 114-4630.

17. Lietuvos Respublikos viešųjų pirkimų ịstatymo pakeitimo įstatymas. Valstybès žinios, 2006, Nr. 4-102.

18. Lietuvos Respublikos Vyriausybės 1992 m. birželio 9 d. nutarimas Nr. 444 „Dèl Valstybinio užsakymo konkurso nuostatų, Valstybinio užsakymo sutarties nuostatų, Valstybinio užsakymo įsipareigojimų nevykdymo nuostolių įvertinimo metodikos patvirtinimo“. Valstybès žinios, 1992, Nr. 24-716.

19. Palidauskaitė J., Ereminaitė S. Korupcija viešuosiuose pirkimuose: nuo teorinès apibrèžties link atvejo studijos (I dalis). Viešoji politika ir administravimas, 2010, 32, 74-84.

20. Prins, J. E. J. Designing E-Government. On the Crossroads of Technological Innovation and Institutional Change. Hague: Kluwer Law International, 2002.

21. Statistics reports under Article XIX:5 of the GPA. World Trade Organization, 2010. http://www. wto.org/english/tratop_e/gproc_e/gpstat_e.htm [2012-05-26].

22. Surandas A. Viešieji pirkimai. Viešųjų pirkimų tarnybos prie Lietuvos Respublikos Vyriausybès informacinis biuletenis, 2002, 1(2), 1-4.

23. Teismų praktikos apžvalga dẻl kvalifikacijos reikalavimų tiekèjams nustatymo ir jų vertinimo. Europos socialinio fondo agentūra, 2010. http://www.esf.lt/uploads/documents/file/ESF\%20 teismams\%20web.pdf [2012-06-15].

24. Tenders Electronic Daily [TED], 2010. http://ted.europa.eu/TED/main/HomePage.do [2012-07$15]$. 
25. Viešieji pirkimai. Lietuvos ekonominès plètros agentūra [LEPA], 2010. http://www.lepa.lt/lt/ ViesiejiPirkimai.html [2012-07-02].

26. Zhou, H. Global Perspectives on E-government. United Nations Division for Public Economics and Public Administration, 2001. http://www.unpan.org/e-government/ZhouE-govUNPAN files/frame.htm [2012-05-25].

Simona Ereminaitè

\section{Assessment Aspects of Electronic Public Procurement Maturity}

Abstract

Public procurement practices are relatively new in the public sector, but everyone knows the complicated regulation and coordination of this process. A number of legislation, which controls a range of public procurement, were legitimated because of the requirement to regulate purchases from national budget, after the restoration of independence of the Republic of Lithuania. The paper analyzes the legal context of the electronic public procurement and particular attention is paid to business development and corporate competitiveness in the EU (European Union).

By 2010, all EU countries should have been installed electronic public procurement systems and at least 50 percent of public procurement should have been made in this way. For a membership of different countries, procurer's participation is essential for EU and the Republic of Lithuania's domestic economy because of safe competition in all EU. Implementation of a model of e-government (electronic government) services, such as government for business and business for government related with electronic public procurement, which helps to reduce bureaucracy, simplifies formal procedures, saves civil servants time and public money, improves product's and service's quality and promotes competition between suppliers, public and private sectors partnership.

E-government is an integral part of modern economics, called as the knowledge economy. E-government helps to reduce bureaucracy and simplify formal procedures, while civil servants are saving time and public money, improves product quality of purchased services and promotes competition between suppliers, public and private sectors collaboration and partnership.

Simona Ereminaitė - Mykolo Romerio universiteto Politikos ir vadybos fakulteto Viešojo administravimo instituto doktoranté, vadybos ir verslo administravimo magistrè.

E. paštas: simona.ereminaite@mruni.eu

Simona Ereminaitè, Master of Management and Business administration, Mykolas Romeris University, Institute of Public Administration, $\mathrm{PhD}$ student.

E-mail: simona.ereminaite@mruni.eu

Straipsnis itteiktas redakcijai 2013 m. liepos 14 d.; recenzuotas; parengtas spaudai $2013 \mathrm{~m}$. spalio mèn. 